somewhat elevated temperature under pressure. I showed that what he regarded as dolomite was not such, but an admixture of carbonate of lime with anhydrous and sparingly soluble carbonate of magnesia ; the conditions in which the carbonate of magnesia is liberated in this reaction not being favourable to its union with the carbonate of lime to form the double salt which constitutes dolomite. The experiment of Marignac, who thought to form dolomite by substituting a solution of chlorid of magnesium for the sulphate, I found to yield similar results, the greater part of the magnesian carbonate produced passing at once into the insoluble condition, without combining with the excess of carbonate of lime present. The process for the production of the double carbonate described by $\mathrm{Ch}$. Deville, namely, the action of vapours of anhydrous magnesian chlorid on heated carbonate of lime, in accordance with Von Buch's strange theory of dolomitisation, I have not thought necessary to submit to the test of experiment, since the conditions required are scarcely conceivable in nature. Multiplied geognostical observations show that the notion of the epigenic production of dolomite from limestone is untenable, although its resolution and deposition in veins, cavities, or pores in other rocks is a phenomenon of frequent occurrence.

The dolomites or magnesian limestones may be conveniently considered in two classes; first, those which are found with gypsums at various geological horizons ; and secondly, the more abundant and widely distributed rocks of the same kind, which are not associated with deposits of gypsum. The production of the first class is dependent npon the decomposition of sulphate of magnesia by solutions of bicarbonate of lime, while those of the second class owe their origin to the decomposition of magnesian chlorid or sulphate by solutions of alkaline bicarbonates. In both cases, however, the bicarbonate of magnesia, which the carbonated waters generally contain, contributes a more or less important part to the generation of the magnesian sediments. The carbonated alkaline waters of deep-seated springs often contain, as is well known, besides the bicarbonates of soda, lime and magnesia, compounds of iron, manganese, and many of the rarer metals in solution, and thus the metalliferous character of many of the dolomites of the second class is explained. The simultaneous occurrence of alkaline silicates in such mineral waters, would give rise, as already pointed out, to the production of insoluble silicates of magnesia, and thus the frequent association of such silicates with dolomites and magnesian carbonates in the crystalline schists is explained, as marking portions of one continuous process. The formation of these mineral waters depends upon the decomposition of feldspathic rocks by subterranean or sub-aërial processes, which were doubtless more active in former ages than in our own. The subsequent action upon magnesian waters of these bicarbonated solutions, whether alkaline or not, is dependent upon climatic conditions, since, in a region where the rainfall is abundant, such waters would find their way down the river-courses to the open sea, where the excess of dissolved sulphate of lime would prevent the deposition of magnesian carbonate. It is in dry and desert regions, with limited lake-basins, that we must seek for the production of magnesian carbonates, and I have argued from these considerations that much of northeastern America, including the present basins of the Upper Mississippi and St. Lawrence, must, during long intervals, in the palæozoic period, have had a climate of excessive dryness, and a surface marked by shallow enclosed basins, as is shown by the widely-spread magnesian limestones, and the existence of gypsum and rock-salt at more than one geological horizon within that area. * The occurrence of serpentine and diallage at Syracuse, New York, offers a curious example of the local development of crystalline magnesian silicates in Upper Silurian dolomitic strata under conditions which are imperfectly known, and which, in the present state of the locality, cannot be studied. $\uparrow$

Since the uncombined and hydrated magnesia mono-carbonate is at once decomposed by sulpbate or chlorid of calcium, it follows that the whole of these lime-salts in a sea-basin must be converted into carbonates before the production of carbonated magnesian sediments can begin. The carbonate of lime formed by the action of carbonates of magnesia and soda, remains at first dissolved as bicarbonate, and is only separated in a solid form, when, in excess, or when required for the needs of living plants or animals, which are dependent for their supply of calcareous matter, on the bicarbonate of lime produced, in part by the process just described, and in part by the action of car-

* Geology of South-western Ontario, Amer. Jour. Sci. II. xlvi. 355

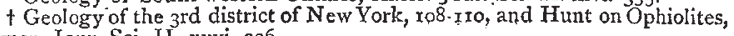
Amer. Jour. Sci, II. xxyi. $23^{6}$. bonic acid on insoluble lime-compounds of the earth's solid crust So many limestones are made up of calcareous organic remains, that a nution exists among many writers on geology that all limestones are, in some way, of organic origin. At the bottom of this lies the idea of an analogy between the chemical relations of vegetable and animal life. As plants give rise to beds of coal, so animals are supposed to produce limestones. In fact, how. ever, the synthetic process by which the growing plant, from the elements of water, carbonic acid and ammonia, generates hydrocarbonaceous and azotised matters, has no analogy with the assimilative process by which the growing animal appropriates alike these organic matters and the carbonate and phosphate of lime. Without the plant, the synthesis of the hydrocarbons would not take place, while independently of the existence of coral or mollusk, the carbonate of lime would still be generated by chemical reactions, and would accumulate in the waters until, these being saturated, its excess would be deposited as gypsum or rock-salt are deposited. Hence, in such waters, where, from any causes, life is excluded, accumulations of pure carbonate of lime may be formed. In I86I I called attention to the white marbles of Vermont, which occur intercalated among impure and fossiliferous beds, as apparently examples of such a process. *

It is by a fallacy similar to that which prevails as to the organic origin of limestones, that Daubeny and Murchison were led to appeal to the absence of phosphates from certain old strata as evidence of the absence of organic life at the time of their accumulation. $\uparrow$ Phosphates, like silica and iron-oxyd, were doubtless constituents of the primitive earth's crust, and the production of apatite crystals in granitic veins, or in crystalline schists, is a process as independent of life as the formation of crystals of quartz or of hematite. Growing plants, it is true, take up from the soil or the waters dissolved phosphates, which passed into the skeletons of animals, a process which has been active from very remote periods. I showed in 1854 that the shells of Lingula and Orbicula, both those from the base of the palrozoic rocks and those of the present time have (like Conularia and Serpulites) a chemical composition similar to the skeletons of vertebrate animals. $*$ The relations of both carbonate and phosphate of lime to organised beings are similar to those of silica, which, like them, is held in watery solution, and by processes independent of life is deposited both in amorphous and crystalline forms, but in certain cases is appropriated by diatoms and sponges, and made to assume organised shapes. In a word, the assimilation of silica, like that of phosphate and carbonate of lime, is a purely secondary and accidental process, and where life is absent, all of these substances are deposited in mineral and inorganic forms.

I have thus endeavoured to sketch, in a concise and rapid manner, the history of the earlier rock-formations of eastern North America, and of our progress in the knowledge of them; while $I$ have, at the same time, dwelt upon some of the geognos. tical and chemical questions which their study suggests. With the record of the last thirty years before them, American geologists have cause for congratulation that their investigations have been so fruitful in yreat results. They see, however, at the same time, how much yet remains to be done in the study of the Appalachians and of our north eastern coast, before the history of these ancient rock-formations can be satisfactorily written. Meanwhile our adventurous students are directing their labours to the vast regions of western America, where the results which have already been obtained are of profound interest. The progress of these investigations will doubtless lead us to modify many of the views now accepted in science, and cannot fail greatly to enlarge the bound of geological knowledge.

\section{THE SCOTTISH SCHOOL OF GEOLOGY $\$$} II.

WHILE Hutton fortified his convictions by constant appeals to the rocks themselves, his disciple Hall tested their truth in the laboratory. It is the boast of Scotland to have led the way in the application of chemical and physical experiment to the elucidation of geological history. It was objected to Hutton's theory, that if basalt and similar rocks had ever been is a

* Amer. Jour. Sci. II. xxxi. 492

+ Siluria, 4th ed. pp. 28 and 537

\$ A Lecture delivered at the opening of the class of Geology and Mineralogy in the University of Edinburgh, by Archibald Geikie, F.R.S., Nov, 6, 187 I,
concluded from P. 39 . 
melted state, they would now have been seen in the condition of glass or slag, and not with the granular or crystalline texture which they actunlly possess. Hall demolished this objection by meliing basalt into a glass, and then by slow cooling reconverting it into a granular substance like the original rock. Hutton hard maintained that under enormous pressure, such as he conceived numst exist under the ocean, or deep within the crust of the earth, even limestone itself might be melted without losing its carbonic acid. This was ridiculed by his opponents, on whom he retorted that they "judged of the great operations of the mineral kingdom from havmg kindled a fire and looked into the bottom of a little crucible." Hall, however, to whom fire and crucible were congenial implements, resolved to put the question to the test of experiment, and though, out of deference to his master, he delayed his task until after the death of the latter, he did at last succeed in converting limestone, under various great pressures, into a kind of marble, and even in reducing it to complete fusion, in which state it acted powerfully on other rocks. He concluded his elaborate essay on this subject with these words, "This single result affords, I conceive, a strong presumption in favour of the solution which Dr. Hutton has advanced of all the geological phenomena; for the truth of the most doubtful principle which be has assumed has thus been established by direct experiment."

Though they saw clearly the proofs which the rocks afford us of former revolutions, neither Hutton nor his friends had any conception of the existence of the great series of fossiliferous formations which has since been unfolded by the labours of later observers-that voluminous record in which the history of life upon this planet has been preserved. They spoke of "Alpine schistus," "primary" or " secondary" strata, as if the geological past had consisted but of two great ages-the second replete with traces of the destruction of the first. "The ruins of an older world," said Hutton, "are visible in the present structure of our planet." He knew nothing of the long, but then undiscovered, succession of such "ruins," each marking a wide interval of time. Nevertheless, for the establishment of the great truths which Hutton laboured to confirm, such knowledge was not necessary. On the other hand, it was most needful that the significance of that discordance between the older and newer strata which Hutton recognised should be persistently proclaimed, And the Huttonians, in spite of their limited range of knowledge and opportunity, saw its value and held by it.

2. But it was not merely, or even chiefly, for their exposition of the structure and history of the rocks under our feet that the geologists of the Scottish School deserve to be held in lasting remembrance. They could not, indeed, have advanced as far as they did in expounding former and ancient conditions of the planet, had they not, with singular clearness, perceived the order and system of change which is in progress over the surface of the globe at the present day. It was their teaching which first led men to see the harmony and co-operation of the forces of nature which work within the earth, with those which are seen and felt Wun its surface. Hutton first caught the meaning of that constant circulation of water which, by means of evaporation, winds, clouds, rain, snow, brooks, and rivers, is kept up between land and sea. He saw that the surface of the dry land is everywhere being wasted and worn away. The scarped cliff, the rugged glen, the lowland valley, are each undergoing this process of destruc tion; wherever land rises above ccean, there, from mountairtop to sea-shore, degradation is continually going on. Here and there, indeed, the debris of the hills may be spread out upon the plains; here and there, too, dark angular peaks and crags rise as they rose centuries ago, and seem to defy the elements. But these are only apparent and not real exceptions to the universal law, that so long as a surface of land is exposed to the at mosphere it must suffer degradation and removal.

But Hutton saw, further, that this waste is not equally distributed over the whole face of the dry land, that while, owing to the greater or less resistance offered by different kinds of rocks, the rate of decay must vary indefinitely, the amount of material must necessarily be greatest where the surplus water flows off towards the sea, that is, along the channels of the streams. Water-courses, he argued, are precisely in the lines which water would naturally follow in running down the slope of the land from its water-shed to the sea, and which, when once selected by the surplus drainage, would necessarily be continually widened and deepened by the excavating power of the rivers. Hence he recored the streams and rivers of a country as following the lines which they had chiselled for themselves out of the solid land, and hus he arrived at the deduction that valleys have been, inch by inch and foot by foot, dug out of the solid framework of the land by the same nalural agents - rain, frost, springs, rivers-by which they are still made wider and deeper. "The mountains," he said, "have been formed by the hollowing ont of the valleys, and the valleys have been hollowed out by the attrition of hard materials coming from the mountains." This is a doctrine which is only now beginning to be adequately realised. Yet to Hutton it was so obvious as to convince him, to use his own memorable worcls, "that the great system upon the surface of this earth is that of valleys and rivers, and that however this system shall be interrupted and occasionally destroyed, it would necessarily be again formed in time while the earth continued above the level of the sea.'

Although these views were again and again proclaimed by Hutton in the pages of his treatise, and though Playfair, catching up the spirit of his master, preached them with a force and eloquence which might almost have insured the triumph of any cause, they met with but scant acceptance. The men were before their time; and thus, while the world gradually acknowledged the teaching of the Scottish school as to the past history of the rocks, it lent an incredulous ear to that teaching when dealing with the present surface of the earth. Even some of the Huttonians themselves refused to follow their master when the sought to explain the existing inequalities of the land by the working of the same quiet unobtrusive forces which are still plying their daily tasks around us. But no incredulity or neglect can destroy the innate vitality of truth. And so now, after the lapse of fully two generations, the views of Hutton have in recent years been re vived, and have become the war-cry of a yearly increasing crowd of earnest hard-working geologists.

While they insisted upon the manifest proofs of constant and universal decay over the surface of the globe, the Scottish geologists no less strongly contended that the decay was a necessary part of the present economy of Nature, that it had been in progress from the earliest periods in the history of the earth, and that it was essential for the presence of organised beings upon the planet. They pointed to the vegetable soil, derived from the decomposition of the rocks which it covers, and necessary for the support of vegetable life. They appealed to the vast quantity of sedimentary rocks forming the visible part of the crust of the earth, and bearing witness in every bed and layer to the degradation and removal of former continents. They showed that the accumulated débris of the land, carried to sea, was there spread out on the sea-floor to form new strata, which, in due time hardened into solid rock, would hereafter be upheaved to form the framework of new lands.

Such was the geology of the Scottish School. It was based not on mere speculation, but on facts drawn from mountain and valley, hill and plain, and tested as far as was then possible by the scrutiny of actual experiment. It strove, for the first time in the history of science, to evolve a system out of the manifold complications of nature, to harmonise what had seemed but the wild random working of subterranean forces with the quiet operations in progress upon the surface of the earth, to understand what is the present system of the world, and through that to peer into the history of the earlier conditions of the planet. It taught that the earthquake and volcano were parts of the orderly arrangement by which new continents were from time to time raised up to supply the place of others which had been worn away; that the surface of the land required to decay to furnish life to plants and animals; that in the removal of the débris thus produced mountains and valleys were carved out; and that in the depths of the ocean there were at the same time laid down the materials for the formation of other lands, which in after ages would be upheaved by underground forces, to be anew worn away as before. The Scottish School proclaimed that in the in. organic world there is ceaseless change, that this change is the central idea of the system, and that in its constant progress lie the conditions necessary for the continuance of our earth as a habitable globe.

That Hutton and his followers should have seen only a part of the truth, that they did not perceive the full scope which their views would ultimately acquire, that they fell into errors, and attached to some secondary parts of their system an importance which we now see to have been misplaced, is only what may be said of any body of men who, at any time, have led the way in a new development of human inquixy. But, after all allowance is made for such shortcomings, we see that their errors were for the most part on mere matters of detail, and that he fundamental principles which they laboured to establish have become the very life and soul of modern geology 
I have spoken of this Scottish School as marking a period of activity which rose into brightness and then waned. It is only too true, that so far as the originality and influence of its cultivators go, Geology has never since held in Scotiand the place which it held here at the beginning of the century. Its decay is perhaps to be ascribed chiefly, if not entirely, to the introduction of the doctrines of Werner from Germany. The Huttonians had dealt rather with general principles than with minute details; they were weak in accurate mineralogical knowledge-not that they were ignorant of or in any degree despised such knowledge ; but it was not necessary for their object. When, however, the system of Werner came to be taught within these walls by his enthusiastic pupil Jameson, its precision and simplicity, and its supposed capability of ready application in every country, joined to the skill and zeal of its teacher, gave it an impulse which lasted for years. I shall have occasion in a subsequent lecture to speak of this system. It is enough for the present to describe it as a crude and artificial attempt to explain the geological history of the globe from the rocks of a district in Saxony. It required mineralogical determination of rocks, and in so far it clid good service, but its theoretical teaching in matters of geology cannot now be regarded without a smile. It maintained that the globe was covered with certain universal formations, and that these had been precipitated successively from solution in a primeval ocean. Of upheaval and subsidence, earthquakes and volcanos, and all the mechanism of internal heat, it could make nothing, and ignored as much as it dared. Werner, the founder of this system, had the faculty of attaching his students to him, and of infusing into them no small share of his own zeal and faith in his doctrines. His pupil Jameson had a similar aptitude. Skilled in the mineralogy of his time, and full of desire to apply the teachings of Freyberg to the explication of Scottish geology or geognosy, as he preferred to call it, he gathered round him a band of active observers, who gleaned facts from all parts of Scotland, and to whom the first accurate descriptions of the mineralogy of the country are due. It is but fitting that a tribute of gratitude should on the present occasion be offered to the memory of Jameson for the life-long devotion with which he taught Natural History, and especially Mineralogy, in this University. His influence is to be judged not by what he wrote, but by the effect of his example, and by the number of ardent naturalists who came from his teaching. He founded a scientific Society here, and called it Wernerian, after his chief-a Society which under his guidance did excellent service to the cause of science in Scotland. And yet in the course of my scientific reading I have never met a sadder contrast than to turn from the earlier volumes of the Royal Society of Edinburgh, containing the classic essays of Hutton, Hall, and Playfair-essays which made an epoch in the history of Geology-to the pages of the Wernerian memoirs, and find grave discussions about the universal formations, the aqueous origin of basalt, and the chemical deposition of such rocks as slate and conglomerate!

Between the followers of Hutton and Werner there necessarily arose a keen warfare. The one battalion of combatants was styled by its opponents "Vulcanists" or "Plutonists," as if they recognised only the power of internal fire, while the other was in turn nicknamed "Neptunists," in token of their acherence to water. The warfare lasted in a desultory way for many years, and though the Wernerian school, having essentially no vitality, eventually died out, and its leader Jameson publicly and frankiy recanted his errors, the early Huttonian magnates had one by one departed and left no successors. The Huttonian school triumphed indeed, but its triumph was seen rather in other countries than ix Scotland. Here the Wernerian school attracted in great measure the younger men who gathered round Jameson, and when its influence waned there were no great names on the other side to rally the thinned and weakened ranks of Huttonianism. Hence came a period of comparative quiescence, which has lasted almost down to our own day. From time to time, indeed, a geologist has arisen among us to show that the science was not dead, and that the doctrines of Hutton had borne good iruit. But Geology has never since held such a prominent place amongst us, nor have the writings of geologists in Scotland taken the same position in the literature of the science. The great name of Lyell, and others of lesser note, have earned elsewhere their title to fame.

But there is one name which must be in our hearts and on our lips to-day, that of Roderick Impey Murchison. To his munificence, and the liberality of the Crown, we owe the foundation of this Chair of Geology, and to his warm friendship I am indebted for the position in which I stand before you, Of his achievements in science, and of the influence of his work all over the world, it is not necessary now to speak. But on Scottish Geology no man has left his name more deeply engraven. It was he who, along with Prof. Sedgwick, first made known the order of succession of the Old Red sandstone of the north of Scotland; it was he who sketched for us the relations of the great Silurian masses of the Southern uplands; and it was he who, by a series of admirable researches, brought order out of the chaos of the so-called Primary rocks of the Highlands, and placed these rocks in a parallel with the Silurian strata of other conntries. These labours will come again before us in detail, and you will then better understand their value, and the debt we owe to the man who accomplished them.

Sir Roderick Murchison looked forward with interest to the occasion which has called us together to-day. Only a few weeks ago I talked with him regarding it, and his eye brightened as I told him of the subject on which I proposed to speak to you. I had hoped that he would have lived to see this day, and to hear at least of the beginning of the work which he has inaugurated for us in this University. But this was not to be. He has been taken from us ripe in years, in work, and in honours, and he leaves us the example of his unwearied industry, his admirable powers of observation, and his rare goodness of heart.

In the course of study now before us, we are to be engaged in examining together the structure and history of the earth. We shall trace the working of the various natural agents which are now carrying on geological change, and by which the past changes of the globe have been effected. In so doing we shall be brought continually face to face with the history of life as recorded in the rocks--for it is by that history mainly that the sequences of geological time can be established. We shall thus have to trespass a little on what is the proper domain of the professors of botany and of natural history. But you will find that no hard line can be drawn between the sciences. Each must needs overlap upon the other; and indeed it is in this rautual interlacing that one great element of the strength and interest of science lies. From Profs. Balfour and Wyville Thomson you will learn the structure and the relation borne to living plants and animals by the fossils with which we shall have to deal as our geological alphabet. By Prof. Crum Brown you are taught the full meaning and application of the chemical laws under which the minerals and rocks, which we in this class must study, have been formed, and of the processes concerned in those subsequent changes, both of rocks and minerals, which are of such paramount importance in Geology.

And now, in conclusion, permit me to give expression to the feelings which must strongly possess the mind of one who is called upon to fill the first Chair dedicated in Scotland to the cultivation of Geology. When I look back to the times of that illustrious group of men-Hutton, Hall, Playfair-who made Edinburgh the special home of Geology ; of Boué and Macculloch, who gave to Scottish rocks and mountains an European celebrity; of Jameson and Edward Forbes, who did so much to stimulate the study of Geology and Mineralogy in this University; and to the memory of Hugh Willer and Charles Maclaren, who fostered the love of the sciences throughout the community here, and to whose kindly friendship and guidance, given to me in my boy. hood, I would fain express my hearty gratitude-when I cast my thoughts back upon these recollections, it would be affectation to conceal the anxiety with which the prospect fills me. The memory of these great names arises continually before me, bear. ing with it a consciousness of the responsibility under which $I$ lie to labour earnestly not to be unworthy of the traditions of the past. And, gentlemen, I feel deeply my responsibility to you who are to enter with me upon a yet untrodden path of the Academic curriculum. It is only experience that will show us how we shall best travel over the wide field before us. In the meantime I must bespeak your kindly forbearance. While I shall cheerfully teach you all I know, and confess what I do not know, I would fain have you in the end to regard me rather in the light of a fellow-student, searching with you after truth, than of a teacher putting before you what is already known. We have now an opportunity of combined and sedulous work which has not hitherto been obtainable in Scotland. We may not rival a Hutton or a Hall ; but we may at least try to raise again the standard of geological inquiry here. On every side of us are incentives to study. Crag and hill rise around us, each eloquent of ancient revolutions, and each a silent witness of the revolution in progress now. At our very gates tower on one side the picturesque memorials of long silent volcanoes, with their crumbling lavas and ashes. On the other lie the buried regetation of an 
ancient land, and the corals and shells of a former ocean. Everywhere the scarred and wasted rocks tell of the degradation of the solid land, and show us how the waste goes on. Let us then carry into our task some share of the enthusiasm which these daily exemplars called forth in earlier days. Let us turn from the lessons of the lecture-room to the lessons of the crags and ravines, appealing constantly to Nature for the explanation and verification of what is taught. And thus, whatsoever may be your career in future, you will in the meantime cultivate habits of observation and communion with the free fresh world around you-habits which will give a zest to every journey, which will enable you to add to the sum of human knowledge, and which will assuredly make you wiser and better men.

\section{SOCIETIES AND ACADEMIES}

\section{LONDON}

Zoological Society, November \%.-Prof. Newton, F.R.S., vice-president, in the chair. The secretary read a report on the additions that had been made to the society's menagerie during the months of June, July, August, and September I871, amongst which were specimens of the Tamandua Ant-eater (Tamandu tetradactyla), Baird's Tapir (Tapirus bairdi), and several other amimals of special interest. - A communication was read from Mr. Gerard Krefft, Curator of the Australian Museum, Sydney N.S.W., containing notes on a rare Ziphioid Whale, which had been stranded near Sydney, and which appeared to be referable to Ziphizes layardi. - Mr. Gould exhibited and characterised a small but lovely Fruit Pigeon from the Fiji Islands, which he proposed to name Chrysena victor.-Mr. Sclater called attention to the supposed existence of an undescribed animal, of about the size of a Dingo, in the Rockingham Bay district of Queensland, and read a letter addressed to him by Mr. Brinsley G. Sheridan, containing particulars on this subject.-Dr. John Anderson, of Calcutta, communicated a description of a short tailed Macaque from Upper Burmah, supposed to be new, which he proposed to call Macacus brunneats. - A communication was read from the to call Macacus brinneats. - A communication was read from the the genus Polihierax, recently obtained by Major Lloyd, in the vicinity of Tongoo, Upper Burmah, and proposed to be called Politicrax insignis. -Mr. W. H.Flower, F.R.S., read a memoir on the recent Ziphioid Whales, among which he proposed to recognise the following generic types:-Hyperoodon, Ziphizus, Mesoplodon, and Berardizts. This was followed by a description of the skeleton of Berardius arnouxii, founded on a specimen lately transmitted to the Museum of the Royal College of Surgeons from New Zealand by Dr. J. Haast, F.R.S. - Mr. Herbert Taylor Usher read some notes on the habits of the Horned Viper (Vipera nasicornis), as observed by him in the vicinity of Cape Coast Castle, Western Africa.-Prof. Newton read a notice of a remarkable peculiarity which he had recently discovered in an Australian duck, Anas punctata, viz., that in this species the osseous development of the lower trachea was common to both sexes.-A paper by Dr. J. C. Cox, of Sydney, was read, describing a new Volute and twelve new species of was Shells from Australia and the Solomon Islands. - A comLand Shells from Australia and the Solomon Islands.-A comGearitish India, containing some remarks on the identification of certain species of Indian Fishes.-Mr. P. L. Sclater, F.R.S., read some notes on Pelicans, being supplementary sclater, subject read at a meeting of the society in May, 1868. - A communication was read from $\mathrm{Mr}$. J. Brazier, of Sydney, containing descriptions of eight new Australian Land Shells. - Prof. Newton communicated a paper by Dr. J. Murie, containing sipplementary notes concerning the powder-down patches of Rhinochetus jubatus.

Anthropological Institute, November 6. - Sir John Lubbock, Bart., F.R.S., president, in the chair. Mr. M. Allport, F. IR S., waselected a corresponding member for Tasmania. - Mr.J W. Flower, F. G.S., treasurer, read a paper "On the relative ages of the Flint and Stone Implement Periods in England." In this paper, which was illustrated by the exhibition of a series of various kinds of flint implements, the author proposed to show, that having regard to recent discoveries, the arrangement hitherto arlopted regarding the Prehistoric Stone period in England as divisible into the Palæolithic and Neolithic was altogether inadeduate, and that as well on Geological as on Palæontological grounds the drift period was separable by a vast interval from that of the bone Caves, as the cave period was separable from the Tumulus or Barrow period. The author adduced various reasons for believing that the implements were made and the drift gravel was thrown down long before this island was severed from the Continent, and that thus before that event both countries were inhabited. He also contended, on this and other grounds founded upon recent discoveries, that the implements could not have been transported (if transported at all by fluviatile action) to the places in which they are found by any rivers flowing in the same channels and draining the same areas as now ; and he also expressed doubts whether the gravels were transported by river action, and also whether the makers of the implements were contemporary with the Mammalia with whose remains they were associated; the gravel and the fossils having been evidently carried from considerable distances, whereas the implements were made on the spot from stones taken from the gravel. $\mathrm{Mr}$. Flower then pointed out that the works of art found in the caves, as well as the animal remains, differed in many important particulars from those found in the drift, and that those of the Tumulus period differed entirely from those in the caves; that in truth the cave fauna had then quite disappeared, and had been succeeded by one entirely different, including most of our domestic animals, and that for effecting such a change an interval of long duration must be allowed. He also pointed out that the use of bronze was common to both what were known as the Palzolithic and Neolithic periods, and could not be regarded therefore as it usually has been, as distinct from and posterior to both ; and, in conclusion, he suggested that the drift period might properly be termed Paleolithic, that of the caves as Archaic, that of the Tumuli as Prehistoric, whilst that of the polished stones might still be known as Neolithic.

Geologists' Association, November 3.--The Rev. Thomas Wiltshire, M.A., F.G.S., president, in the chair. "On the old Land Surfaces of the Globe," by Prof. Morris, F.G.S. The indications of land surfaces to be found in Palrozoic, Mesozoic, and Cainozoic strata were recapitulated. Conglomerates and ripple marks, as well as the great thiclnness of the oldest sedimentary rocks, the result of denudation, clearly show the existence of land during Cambrian and Silurian times. Though there are indications of vegetable life in Cambrian rocks, the earliest remains of vegetable organisms allied to our present land plants occur in the uppermost Silurian Strata, or passage beds. The Old Red sandstone of Scotiand affords evidence of fresh-water origin and consequently of lakes and land. But in carboniferous rocks we have in the vast accumulations of vegetable remains forming the great coal beds of the world, perhaps the most striking and conclusive proof of land and terrestrial conditions to be found in the geologic record. After noticing the indications of land in the Permian rocks, the Mesozoic reptilia and mammalia, as well as the many other evidences of land surfaces to be met with in the Secondary rocks, were dwelt upon; and a similar review of Cainozoic, or Tertiary, terrestrial indications was followed by an exposition of the upward and onward progress of life, culminating in the present conditions of the globe with a flora and a fauna admirably adapted to the wants of the latest addition to the marvels of the universe, man, whose duty it is, and whose pleasure it ought to be, to study those successive changes, the grand result of which he now enjoys.-A note "On recent exposure of the Glacial Drift at Finchley" was read by Mx. $H$. Walker. This was a brief notice, and intended as an introduction of the subject, which will be more fully elucidated in a paper by the same author to be read at the next meeting of the association.

Society of Biblical Archæology, November 7.-Dr. S. Birch, president, in the chair. Dr. Richard Cull, F.S.A. read a paper contributed by Mr. Henry Fox Talbot, F.R.S., "On the Religious Beliefs of the Assyrians."-Mr. R. Hamilton Lang, H.B.M. Consul at Cyprus, read a papex "On the Discovery of some Cypriote Inscriptions." After stating that the credit was due to Duc de Luynes of having proved the existence of a Cypriote alphabet, he enumerated the various inscriptions which he had himself discovered, and drew especial attention to one, a bi-lingual inscription in Phœnician and Cypriote, which he first discovered during the excavation of a temple at Idalion. The alphabet, which had been compiled by the Duc de Luynes, consisted of 80 letters, but Mr. Lang felt justified in reducing that number to $5 \mathrm{I}$, and exhibited an alphabet which he believed to contain all the Cypriote characters of which we are at present certain. In proceeding he dwelt at some length upon an apparent resemblance between 